\title{
SISTEM PENUNJANG KEPUTUSAN DALAM PEMILIHAN GURU TERBAIK PADA SMA MUHAMMADIYAH 15 JAKARTA MENGGUNAKAN METODE ANALYTICAL HIERARCHY PROCESS (AHP) DAN SIMPLE ADDITIVE WEIGHTING (SAW)
}

\author{
Sugeng Riadi ${ }^{1}$, Humisar Hasugian ${ }^{2}$ \\ ${ }^{1}$ Sistem Informasi, Fakultas Teknologi Informasi, Universitas Budi Luhur \\ ${ }^{1,2} \mathrm{Jl}$. Raya Ciledug, Petukangan Utara, Kebayoran Lama, Jakarta Selatan 12260 \\ E-mail : sugengr7@gmail.com ${ }^{1)}$, humisar.hasugian@budiluhur.ac.id ${ }^{2)}$
}

\begin{abstract}
Abstrak
Guru merupakan salah satu komponen yang penting dalam dunia pendidikan. guru yang berkompeten dan mempunyai kemampuan yang baik dalam pembelajaran di sekolah memungkinkan peserta didik memperoleh ilmu pengetahuan dan wawasan yang luas dalam hal-hal yang dipelajari disekolah. SMA Muhammdiyah adalah lembaga dibidang pendidikan. Permasalahan yang di hadapi sistem yang berjalan pada SMA Muhammdiyah 15 Jakarta saat ini adalah masih belum menggunakan metode dalam pemilihan guru terbaik, belum ada perangkingan dalam pemilihan guru terbaik. Untuk mengatasi permasalahan yang ada, maka penulis menggunakan metode Analytical Hierarchy Process (AHP) untuk penentuan bobot kriteria.. yaitu dengan membandingkan kriteria dibandingkan dengan kriteria lainya hingga kriteria mempunyai bobot dan menggunakan metode Simple Additive Weighting (SAW) sebagai metode untuk perangkingan pemilihan guru terbaik. Dalam hal ini, dilakukan dengan menjumlahkan bobot dari setiap guru untuk semua atribut penilaian. Aplikasi penunjang keputusan yang dibangun Pada SMA Muhammadiyah 15 Jakarta menggunakan bahasa pemrograman Microsoft Visual Studio 2008 sebagai tools serta menggunakan database MySql.
\end{abstract}

Kata kunci: Guru, AHP, SAW, Sistem Penunjang Keputusan

\section{PENDAHULUAN}

SMA Muhammadiyah 15 Jakarta merupakan lembaga di bidang pendidikan. guru yang berkompeten, dapat membuat siswa-siswi memperluas wawasan akan ilmu pengetahuan sesuai dengan kurikulum sekolah. Sehingga untuk memenuhi kebutuhan akan guru yang berkompeten, maka perlu dibuatkan sebuah sistem. Tujuan diadakan penelitian ini, memudahkan pengambil keputusan dalam menentukan kinerja guru terbaik yang berkompeten sesuai dengan kriteria dan kompetensi yang sudah ditentukan oleh SMA Muhammadiyah 15 Jakarta. Masalah yang dihadapi pada SMA Muhamadiyah 15 Jakarta adalah:

1. Belum ada perangkingan dalam pemilihan guru terbaik pada SMA Muhammadiyah 15 Jakarta.

2. Proses rekap data membutuhkan waktu yang lama.

3. Pemilihan guru terbaik saat ini kurang efektif karena dalam pemilihan guru belum menggunakan metode.

Metode Analytical Hierarchy Process (AHP) digunakan untuk pembobotan pada kriteria dan Simple Additive Weighting (SAW) yang menghasilkan ranking pemilihan guru terbaik dalam penelitian ini.

\section{PENELITIAN SEBELUMNYA}

\subsection{Definisi Sistem}

(Sutabri, 2012) pada buku Konsep Sistem Informasi mendefinisikan sistem sebagai berikut: "Suatu sistem pada dasarnya adalah sekelompok unsur yang erat hubungannya satu dengan yang lain yang berfungsi bersama-sama untuk mencapai tujuan tertentu”. [1]

\subsection{Definisi Sistem Penunjang Keputusan}

(Turban, E. et al, 2010) mengemukakan "Decision Support System (DSS) atau Sistem Penunjang Keputusan (SPK) adalah sistem yang dimaksudkan untuk mendukung pembuatan keputusan manajerial dalam situasi keputusan semi terstruktur dan terstruktur”. [2]

\subsection{Pengertian Guru}

Dinyatakan bahwa guru mempunyai fungsi, peran dan kedudukan yang sangat strategis dalam pembangunan nasional dibidang pendidikan. Selain iu juga membimbing, mendidik, menilai pada pendidikan usia dini, dasar dan pendidikan menengah peserta didik jalur pendidikan formal. [3]

\subsection{Studi Literatur Review}

Berikut adalah studi literatur review berdasarkan penelitian serupa yang telah terpublikasi: 
a. Sistem Pendukung Keputusan Pemilihan Guru Terbaik Pada SMK Maria Goretti Pematangsiantar Menggunakan Metode Simple Additive Weighting (SAW) (Hutasoit dkk, 2016). [4]

b. Sistem Penunjang Keputusan Pemilihan Pegawai Terbaik dengan Metode Analytical Hi rarchy Process (AHP) dan Simple Additive We ghting (SAW) (Studi Kasus : PT Sukma Jaya Ma diri) (Hasuian Humisar, Putra Esa, 2014). [5]

\section{METODE PENELITIAN}

\subsection{Identifikasi Masalah}

Pada tahap ini penulis mengidentifikasi masalah yang terjadi pada SMA Muhammadiyah 15 Jakarta dengan melihat terlebih permasalahan yang sedang dihadapi.

\subsection{Metode Pengumpulan Data Informasi}

Dalam penelitian ini, pengumpulan data dilakukan beberapa tahap sebagai berikut:

1. Metode Wawancara

melakukan dengan cara tanya jawab dengan narasumber, untuk mengetahui permasalahan yang dihadapi.

2. Metode Observasi

Mengamati langsung proses bisnis berjalan pada SMA Muhammadiyah 15 Jakarta.

3. Analisis Dokumen

Dengan cara mengumpulkan data dan melakukan analisa dokumen. berdasarkan dokumendokumen yang terkumpul, maka penulis memberikan penjelasan singkat mengenai fungsi dari dokumen-dokumen tersebut.

\subsection{Kerangka Pemikiran}

Kerangka pemikiran yang digunakan dalam menjelaskan sistem dengan suatu pendekatan tertentu pada gambar 1 :

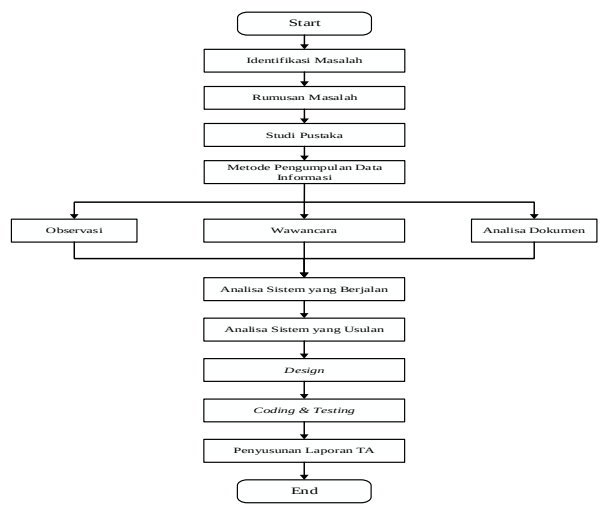

Gambar 1. Kerangka pemikiran

\section{HASIL DAN PEMBAHASAN}

4.1. Sejarah Organisasi

Sekolah Menengah Atas Muhammadiyah 15 Jakarta merupakan sebuah sekolah dengan kurikulum Pengetahuan Umum dari Kementrian Pendidikan Nasional tertanggal 5 Juni 1989 Nomor Kep.037/101.A1/1/89. berdiri didalam Komplek Perguruan Muhammadiyah, SMA Muhammadiyah 15 Jakarta terletak di Jalan Anggrek Neli Murni, B-C Slipi, Kecamatan Palmerah, Jakarta Barat

\subsection{Struktur Organisasi}

Struktur organisasi pada SMA Muhammadiyah 15 Jakarta ditunjukkan gambar 2:

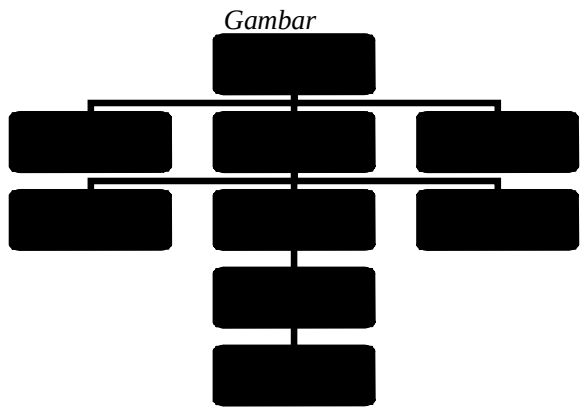

\subsection{Proses Bisnis Sistem Berjalan}

Berikut adalah kegiatan dalam proses bisnis sistem berjalan, sebagai berikut:

Proses pemilihan guru terbaik pada SMA Muhammadiyah 15 Jakarta dilakukan 1 (satu) kali setiap tahun. Bidang kurikulum memulai penilaian dengan melihat kegiatan guru di dalam kelas. Kemudian bidang kurikulum melakukan penilaian pada guru yang akan dinilai. Setelah itu bidang kurilulum memberi penilaian, lalu bidang kuriklulum memberi hasil penilaian guru kepada Kepala Sekolah. kemudian Kepala Sekolah mengadakan Rapat dan mengumumkan hasil Penilaian Guru di dalam rapat guru SMA Muhammadiyah 15 Jakarta, seperti gambar 3

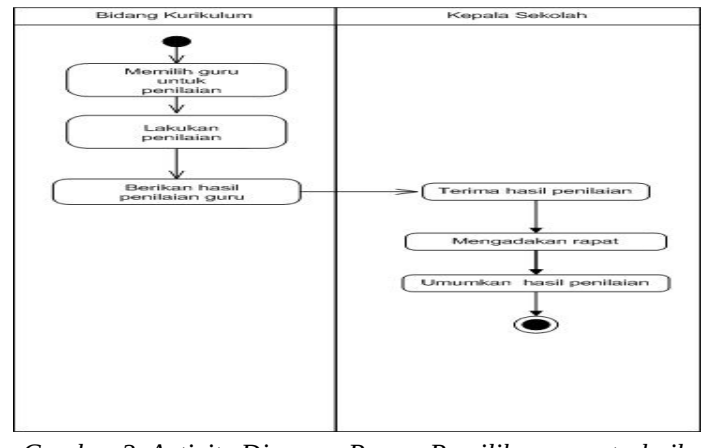

Gambar 3. Activity Diagram Proses Pemilihan guru terbaik 


\subsection{Analisa Masalah}

Dalam menganalisa masalah pada pengambilan keputusan dalam menentukan guru terbaik, penulis menggunakan fishbone diagram seperti pada gambar 4.

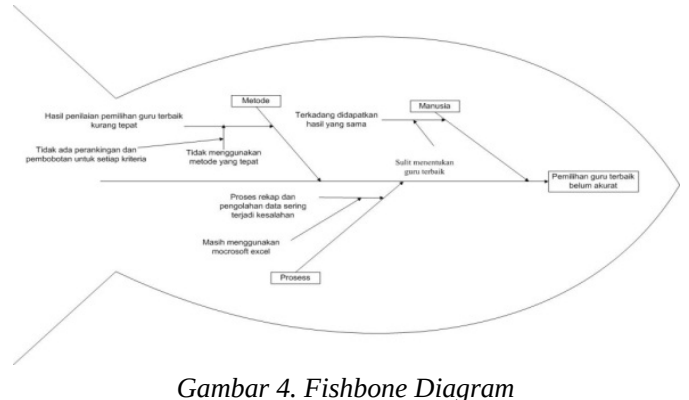

Berikut adalah penjelasan dari fishbone diagram di atas: faktor-faktor kesulitan dalam pengambilan keputusan pemilihan guru terbaik pada SMA Muhammadiyah 15 Jakarta :

1. Faktor Manusia, sulitnya dalam menentukan guru terbaik yang disebabkan oleh terdapat hasil yang sama.

2. Faktor Proses, mengakibatkan proses rekap dan pengolahan data guru terbaik masih sulit.

3. Faktor Metode, yang disebabkan tidak adanya ranking guru dan belum menggunakan metode pada pemilihan guru terbaik.

\subsection{Metode Analytical Hierarchy Process (AHP)}

Pada dasarnya sistem pendukung keputusan merupakan pengembang lebih lanjut dari sistem informasi manajemen terkomputerisasi. Sistem penunjang keputusan dirancang sedemikian rupa sehingga bersifat interaktif. Sifat interaktif dimaksudkan untuk memudahkan integrasi antara berbagai komponen dalam proses pengambilan keputusan seperti prosedur, kebijakan, teknik analisis, serta pengalaman dan wawasan manajerial guna membentuk suatu kerangka keputusan bersifat fleksibel (Turban, E. et al, 2010)

\subsection{Pengolahan Data Kriteria Dalam Pemilihan Guru Terbaik}

Berikut adalah kriteria yang digunakan sebagai dasar pemilihan guru terbaik. Kriteria tersebut terbagi menjadi 3 (tiga) antara lain: Kehadiran, nilai RPP, Jenjang Pendidikan. Nilai perbandingan kepentingan antar kriteria adalah sebagai berikut:

1) Kehadiran 4 (empat) kali lebih penting dari nilai RPP.

2) Kehadiran 8 (delapan) kali lebih penting dari Jenjang Pendidikan.
3) nilai RPP 2 (dua) kali lebih penting dari jenjang Pendidikan.

\subsection{Menentukan Bobot Masing-Masing Kriteria Dengan Metode Analytical Hierarchy Process (AHP)}

Berdasarkan tingkat kepentingan diatas, terdapat pada tabel 1 :

Tabel 1. Matriks Perbandingan Kepentingan Per Kriteria

\begin{tabular}{|l|l|l|l|}
\hline Kriteria & Kehadiran & $\begin{array}{l}\text { Nilai } \\
\text { Rpp }\end{array}$ & $\begin{array}{l}\text { Jenjang } \\
\text { Pendidikan }\end{array}$ \\
\hline Kehadiran & 1 & 4 & 8 \\
\hline Nilai Rpp & $1 / 4$ & 1 & 2 \\
\hline $\begin{array}{l}\text { Jenjang } \\
\text { Pendidikan }\end{array}$ & $1 / 8$ & $1 / 2$ & 1 \\
\hline
\end{tabular}

Langkah-langkah dalam metode Analytical Hierarchy Process (AHP) adalah sebagai berikut:

1) Langkah 1

Menjabarkan matriks di atas ke dalam bentuk desimal:

$[1,00004,00008,0000]$

$0,25001,00002,0000$

$0,12500,50001,0000$

2) Langkah 2

Mengalikan matriks dengan dirinya sendiri:

$[1,00004,00008,0000] \quad[1,00004,00008,0000]$

$0,25001,00002,0000 \times 0,25001,00002,0000$

$0,12500,50001,0000] \times\left[\begin{array}{l}0,25001,00002,000 \\ 0,12500,50001,0000\end{array}\right]$

3) Langkah 3

Hasil dari perkalian matriks (langkah 2):

$[3,000012,000024,0000]$

$0,75003,00006,0000$

$0,37501,50003,0000$

4) Langkah 4

Jumlahkan tiap baris hasil dari perkalian matriks:

$$
\frac{\left[\begin{array}{l}
39,0000 \\
9,7500 \\
4,8750
\end{array}\right]}{53,6250}+
$$

5) Langkah 5

Menormalisasikan hasil tiap baris yang akan dibagi total baris dan didapatkan eigenvector:

$$
\frac{\left[\begin{array}{c}
39,0000 \\
9,7500 \\
4,8750
\end{array}\right]}{53,6250}
$$

$$
\frac{\left[\begin{array}{l}
0,4439 \\
0,1684 \\
0,3878
\end{array}\right]}{1,0000}
$$

Eigenvector 
6) Langkah 6

Setelah itu tentukan bobot dari masing-masing kriteria.

Tabel 2. Bobot Kriteria

\begin{tabular}{|l|r|}
\hline Nama Kriteria & \multicolumn{1}{|l|}{ Bobot } \\
\hline Kehadiran & $72,73 \%$ \\
\hline Nilai Rpp & $18,18 \%$ \\
\hline Jenjang Pendidikan & $9,09 \%$ \\
\hline Bobot & $100 \%$ \\
\hline
\end{tabular}

\subsection{Pengujian Metode Analytical Hierarchy Process (AHP)}

Pengujian model Analytical Hierarchy Process (AHP) dimulai dengan hitung nilai Consistency Index (CI) dan nilai Consistency Ratio (CR) dengan tahapan sebagai berikut:

1) Tahap pertama

Nilai bilangan desimal dari setiap matriks kriteria dikalikan dengan eigenvector:

Tabel 3 Perkalian Matriks Kriteria dengan

Eigenvector

\begin{tabular}{|c|c|c|c|c|c|c|c|}
\hline Kriteria & $\begin{array}{c}\text { Kehadi } \\
\text { ran }\end{array}$ & $\begin{array}{c}\text { Nilai } \\
\text { Rpp }\end{array}$ & $\begin{array}{c}\text { Jenjang } \\
\text { Pendidi } \\
\text { kan }\end{array}$ & & $\begin{array}{c}\text { Eigenv } \\
\text { ector }\end{array}$ & Hasil \\
\hline Kehadiran & 1,0000 & 4,0000 & 8,0000 & & 0,7273 & $=2,1817$ \\
\hline Nilai Rpp & 0,2500 & 1,0000 & 2,0000 \\
\cline { 1 - 4 } $\begin{array}{c}\text { Jenjang } \\
\text { Pendidikan }\end{array}$ & 0,1250 & 0,5000 & 1,0000 & 0,1818 & $=0,5454$ \\
\cline { 1 - 2 } & & & 0,0909 & $=$ & 0,2727 \\
\hline
\end{tabular}

\section{2) Tahap 2}

Hitung Consistency Vector dengan cara hasil perkalian matriks dengan dibagi bobot perkrieria dan menentukan nilai rata-rata dari Weighted Sum Vector.

$$
\begin{array}{lllll}
2,1817 & : & 0,7273 & & 2,9997 \\
0,5454 & : & 0,1818 & = & 3,0000 \\
0,2727 & : & 0,0909 & = & 3,0000
\end{array}
$$

3) Tahap 3 (CI)

Hitung nilai rata-rata dari Consistency Vector

$\Pi=\frac{(2,9997+3,0000+3,0000)}{3}=2,9999$

4) Tahap 4

Hitung nilai Consistency Index dengan menggunakan rumus:

$$
\begin{aligned}
C I & =\frac{(\pi-n)}{n-1} \\
n & =\text { jumlah kriteria }
\end{aligned}
$$

$$
\mathrm{CI}=\frac{(2,9999-3)}{3-1}
$$

$$
\mathrm{CI}=0
$$

\section{5) Tahap 5}

hitung Consistency Ratio, ada nilai RI yaitu Random Index yang didapat dari tabel Oak Ridge $C R=\frac{C I}{R I}$

$$
\begin{aligned}
& \text { untuk } \mathrm{n}=3 \text { maka } R I \text { adalah } 0,58 \\
& C R=\frac{0}{0,58} \\
& C R=0
\end{aligned}
$$

Jadi nilai Consistency Ratio (CR) untuk kriteria terbaik pada SMA Muhammadiyah 15 Jakarta adalah 0. Penilaian perbandingan dikatakan konsisten jika Consistency Ratio (CR) tidak lebih dari 0,1000 . semestinya perhitungan nilai perbandingan antar kriteria pemilihan Guru terbaik sudah konsisten.

\subsection{Model Keputusan Dengan Simple Additive Weighting (SAW)}

Metode Simple Additive Weighting (SAW) sebagai perangkingan alternatif dalam pemilihan guru terbaik. Hasil ranking tersebut didapatkan dari perhitungan nilai akhir guru. Alternatif yang dimaksud adalah guru SMA Muhammadiyah 15 Jakarta. Kriterianya terdiri dari kriteria Kehadiran, Nilai RPP serta Jenjang Pendidikan dan hasil perhitungan akan menghasilkan hasil nilai akhir dari guru. Tahapan-tahapan nya sebagai berikut :

1. Kriteria dan Bobot

Tahap satu, menggunakan metode Analytical Hierarchy Process (AHP), jika keseluruhan bobot yang didapat $100 \%$.

Tabel 4. Persentase Bobot Kriteria

$\begin{array}{ccc}\text { Kode Kriteria } & \text { Nama Kriteria } & \text { Bobot } \\ \text { KRT01 } & \text { Kehadiran } & 72,73 \% \\ \text { KRT02 } & \text { Nilai Rpp } & 18,18 \% \\ \text { KRT03 } & \text { Jenjang Pendidikan } & 9,09 \% \\ & \text { Total Bobot } & 100 \%\end{array}$

\section{Matriks Normalisasi}

Berdasarkan banyaknya guru di SMA Muhammadiyah 15 Jakarta, maka diambil 5 (lima) guru sebagai contoh dalam pemilihan guru terbaik.

Tabel 5. Nilai Alternatif Per Kriteria

\begin{tabular}{llll}
\multicolumn{1}{c}{ Alternatif } & \multicolumn{1}{c}{ KRT01 } & Kriteria & \\
Leni Oktaviani, S.Pd & 96,83 & 88 & KRT03 \\
Vidia Laila, S.Bio & 84 & 90 & 1 \\
Rita Lestari S.Pd & 97,67 & 86 & 1 \\
Setianingsih, S.T & 100 & 88,89 & 1 \\
Mariamah,S.Pd & 98,17 & 85 & 1
\end{tabular}


Tahap satu adalah dilakukan normalisasi jadi matriks, lalu menghitung nilai masing-masing kriteria, lalu hitung sesuai dengan kriteria keuntungan (benefit) atau kriteria biaya (cost) dengan persamaan sebagai berikut:

$$
r_{i j}=\left\{\begin{array}{l}
\frac{X_{I J}}{\operatorname{Max}_{i} X_{i j}} \\
\frac{\operatorname{Min}_{i} X_{i j}}{X_{i j}}
\end{array}\right.
$$

Jika j adalah atribut keuntungan (benefit)

Jika j adalah atribut biaya (cost)

Keterangan

$r_{i j}=$ nilai rating kinerja ternormalisasi

$X_{i j}=$ nilai atribut yang dimiliki dari setiap

kriteria

$\operatorname{Max}_{i} X_{i j}=$ nilai terbesar alternatif dari setiap

kriteria i

$\operatorname{Min}_{i} X_{i j}=$ nilai terkecil alternatif dari setiap

kriteria i

Benefit $=$ jika nilai terbesar yang terbaik

Cost $=$ jika nilai terkecil yang terbaik

Tabel 6. Penggolongan Kriteria

\begin{tabular}{lcc}
\multicolumn{1}{c}{ KRITERIA } & BENEFIT & COST \\
Kehadiran & $\checkmark$ \\
Nilai Rpp & $\checkmark$ \\
Jenjang Pendidikan & $\checkmark$
\end{tabular}

Tahap ini adalah setiap kriteria dihitung kemudian didapatkan hasil penilaian dari masingmasing guru.

1. Menghitung Kriteria Kehadiran

$$
\begin{aligned}
& \mathrm{R} 11 \frac{96,83}{\max (100 ; 84 ; 97,67 ; 90 ; 98,17)}=\frac{96,83}{100}=0,9683 \\
& \mathrm{R} 21 \frac{84}{\max (100 ; 84 ; 97,67 ; 90 ; 98,17)}=\frac{84}{100}=0,8400 \\
& \mathrm{R} 31 \frac{97,67}{\max (100 ; 84 ; 97,67 ; 90 ; 98,17)}=\frac{97,67}{100}=0,9767 \\
& \mathrm{R} 41 \frac{100}{\max (100 ; 84 ; 97,67 ; 90 ; 98,17)}=\frac{100}{100}=1,0000 \\
& \mathrm{R} 51 \frac{98,17}{\max (100 ; 84 ; 97,67 ; 90 ; 98,17)}=\frac{98,17}{100}=0,9817
\end{aligned}
$$

2. Perhitungan Kriteria Nilai RPP

$$
\begin{aligned}
& \mathrm{R} 12 \frac{78}{\max (78 ; 90 ; 86 ; 88,89 ; 85)}=\frac{78}{90}=0,8667 \\
& \mathrm{R} 22 \frac{90}{\max (78 ; 90 ; 86 ; 88,89 ; 85)}=\frac{90}{90}=1,0000
\end{aligned}
$$

$$
\begin{aligned}
& \text { R32 } \frac{86}{\max (78 ; 90 ; 86 ; 88,89 ; 85)}=\frac{86}{90}=0,9556 \\
& \mathrm{R} 42 \frac{88,89}{\max (78 ; 90 ; 86 ; 88,89 ; 85)}=\frac{88,89}{90}=0,9877 \\
& \mathrm{R} 52 \frac{85}{\max (78 ; 90 ; 86 ; 88,89 ; 85)}=\frac{85}{90}=0,9444
\end{aligned}
$$

3. Perhitungan Kriteria Jenjang Pendidikan

$$
\begin{aligned}
& \mathrm{R} 13 \frac{1}{\max (1 ; 1 ; 1 ; 1 ; 1)}=\frac{1}{1}=1,0000 \\
& \mathrm{R} 23 \frac{1}{\max (1 ; 1 ; 1 ; 1 ; 1)}=\frac{1}{1}=1,0000 \\
& \mathrm{R} 33 \frac{1}{\max (1 ; 1 ; 1 ; 1 ; 1)}=\frac{1}{1}=1,0000 \\
& \mathrm{R} 43 \frac{1}{\max (1 ; 1 ; 1 ; 1 ; 1)}=\frac{1}{1}=1,0000 \\
& \mathrm{R} 53 \frac{1}{\max (1 ; 1 ; 1 ; 1 ; 1)}=\frac{1}{1}=1,0000
\end{aligned}
$$

kemudian nilai $\mathrm{R}$ yang didapat, dilanjutkan dengan tahap lain yaitu dengan proses nilai preferensi dengan persamaan sebagai berikut :

$$
V i=\sum_{j=1}^{n} W j \Gamma i j
$$

1) Leni Oktavia

$$
=\{(0,9683 \times 0,7273)+(0,8667 \times 0,1818)+
$$

$(1 \times 0,0909)\}=(0,7043+0,1576+0,0909)=$ 0,9527

2) Vidia Laila

$=\{(0,8400 \times 0,7273)+(1 \times 0,1818)+(1 \times$ $0,0909)\}=(0,6109+0,1818+0,0909)=0,8836$

3) Rita Lestari

$=\{(0,9767 \times 0,7273)+(0,9556 \times 0,1818)+$

$(1 \times 0,0909)\}=(0,7103+0,1737+0,0909)=$ 0,9750

4) Setianingsih

$=\{(1,0000 \times 0,7273)+(0,9877 \times 0,1818)+$

$(1 \times 0,0909)\}=(0,7273+0,7196+0,0909)=$ 0,9978

5) Mariamah

$$
=\{(0,9817 \times 0,7273)+(0,9444 \times 0,1818)+(1
$$

$\mathrm{x} 0,0909)\}=(0,7139+0,1716+0,0909)=0,9764$

Dari perhitungan alternatif diatas didapatkan :
1) Setianingsih : Ranking 1
2) Mariamah : Ranking 2
3) Rita Lestari : Ranking 3
4) Leni Okaviani : Ranking 4
5) Vidia Laila : Ranking 5

Sehingga dapat disimpulkan bahwa nilai terbesar diperoleh Setianingsih, SPd sebagai alternatif terbaik dengan Nilai 0,9978. 


\subsection{Use Case Diagram Input} Input

Input

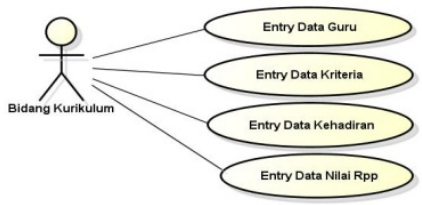

Gambar 5. Use Case Diagram Input

\subsection{Model Data}

Class diagram yang digunakan pada penelitian ini ditunjukkan pada gambar 6:

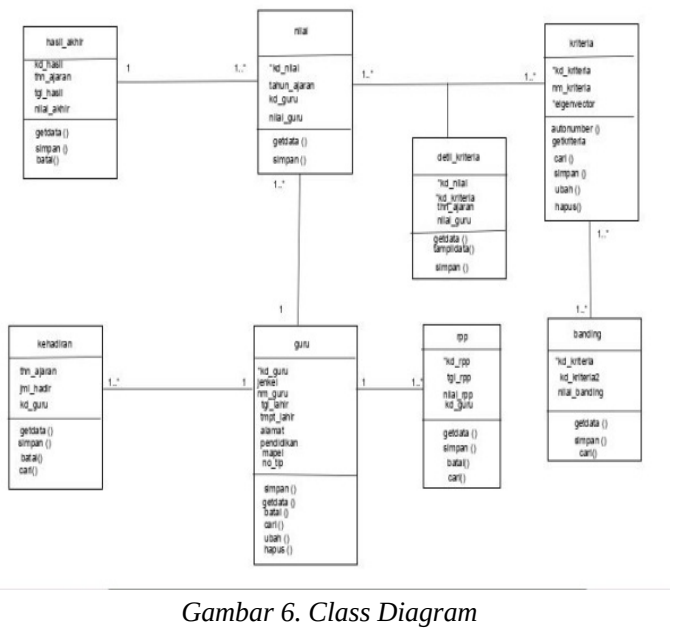

\subsection{Struktur Tampilan}

Berikut adalah struktur tampilan menu utama seperti pada gambar 7:

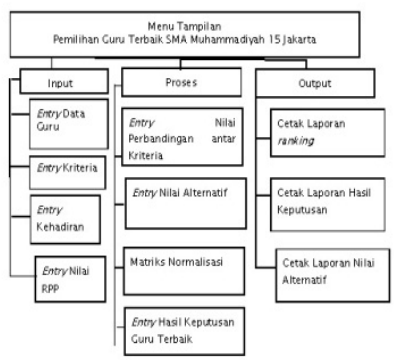

Gambar 7. Struktur Tampilan

\subsection{Rancangan Layar}

Pada form entry data guru terdapat Kode Guru akan tampil secara otomatis dengan menggunakan fungsi autonumber pada textbox kode guru. Ada alamat, jenis kelamin, tempat lahir, tanggal lahir, pendidikan dan nomor telepon kemudian untuk menyimpan data guru, jika proses input telah selesai, user dapat klik tombol simpan untuk menyimpan data dan tombol batal untuk batal seperti pada gambar 8 .

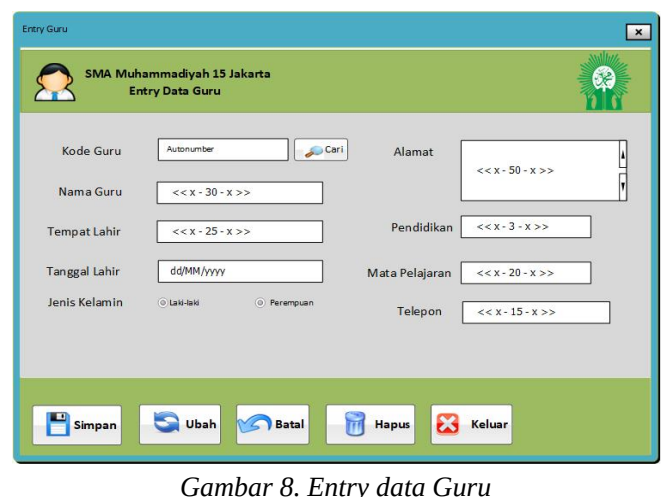

\subsection{Form Entry Data Kehadiran}

Form ini digunakan untuk menginput dan menghitung jumlah rata-rata kehadiran guru pertahun. Kode Kehadiran akan otomatis dengan menggunakan fungsi autonumber pada textbox kode kehadiran. User memilih tahun ajaran pengentrian kehadiran pada combo box tahun ajaran. Pada form ini terdapat kode guru, nama guru, tahun Ajaran dan Jumlah hadir . User memilih guru yang ingin di input data kehadirannya dengan pilih buttton cari. Kemudian data akan tampil, lalu pilih data yang ingin di input data kehadiranya. Kemudian user mengisi jumlah kehadiran guru pada textbox setelah itu input jumlah kehadiran. Jika proses input telah selesai, user dapat klik tombol simpan untuk menyimpan data atau tombol batal untuk batal seperti pada gambar 9 .

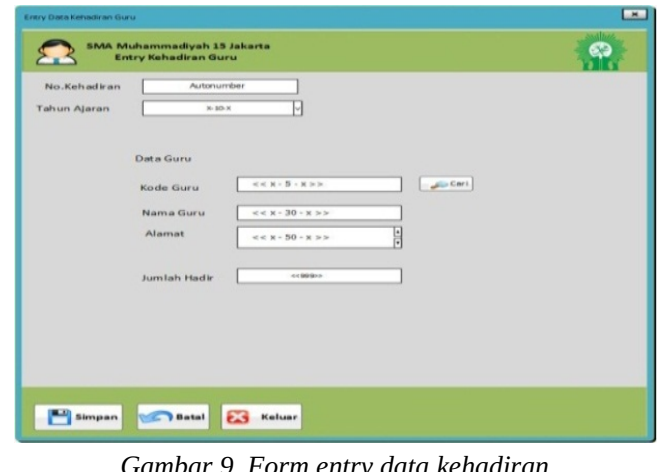




\section{KESIMPULAN}

Berdasarkan penelitian yang telah dilaksanakan di SMA Muhammadiyah 15 Jakarta, terdapat beberapa kesimpulan yang dapat diambil antara lain:

1. Setelah adanya sistem penunjang keputusan mengunakan metode Simple Additive Weighting (SAW masing-masing guru mempunyai ranking. Hasil yang didapatkan dengan metode Simple Additive Weighting (SAW), guru yang mendapatkan ranking pertama adalah Setianingsih dengan nilai (0,9978).

2. Dengan adanya sistem penunjang keputusan guru terbaik ini proses rekap data lebih mudah dan cepat dalam proses pemilihan guru terbaik.

3. Adanya sistem penunjang keputusan pada pemilihan guru terbaik dapat menghasilkan keputusan yang tepat karena menggunakan metode yaitu Analytical Hierarchy Process (AHP) sebagai priotitas pembobotan kriteria yang digunakan dan metode Simple Additve Weighting (SAW) sebagai Penjumlahan bobot kriterias dan perangkingan alternatif.

\section{UCAPAN TERIMA KASIH}

Penulis ingin mengucapkan terima kasih telah memberikan bantuan dan dorongan serta motivasi sehingga penulis dapat menyelesaikan penelitian ini dengan sebaik-baiknya, terutama kepada :

1. Allah Subhanahu Wa Ta' ala atas berkah, rahmat, nikmat dan hidayah-Nya sehingga akhirnya penulis dapat menyelesaikan Laporan Tugas Akhir (TA).

2. Orang Tua serta keluarga tercinta yang telah memberikan dukungan baik secara moril dan material.

3. Bapak Dr. Ir. Wendi Usino, M.Sc.,MM selaku Plt. Rektor Universitas Budi Luhur.

4. Bapak Dr. Deni Mahdiana, S.Kom, M.M., M.Kom. selaku Dekan Fakultas Teknologi Informasi Universitas Budi Luhur.

5. Ibu Dr. Rusdah, S.Kom, M.Kom. selaku Ketua Program Studi Sistem Informasi, Fakultas Teknologi Informasi Universitas Budi Luhur.

6. Bapak Humisar Hasugian, S.Kom, M.Kom. sebagai Dosen Pembimbing yang membimbing dengan ketegasan dan kesabaranya serta masukan sampai laporan penelitian ini selesai.

7. Segenap Dosen Fakultas Teknologi Informasi, Universitas Budi Luhur yang telah memberikan ilmunya kepada penulis dalam menempuh pendidikan.
8. Bapak Asrunnas Imran, M.Pd selaku Kepala Sekolah SMA Muhammadiyah 15 Jakarta.

9. Teman-teman seperjuangan semasa kuliah Angkatan 2014 yang tidak disebutkan satupersatu.

\section{DAFTAR PUSTAKA}

[1] Sutabri, Tata. Konsep Dasar Informasi. Yogyakarta: Andi Offset, 2012.

[2] Turban, Efraim, Sharda, Ramesh, Delen, Dursun. Decision Support and Business Intelligence System, $9^{\text {th }}$ ed, New Jersey : Prentice-Hall Inc, 2010.

[3] (2005) Peraturan go.id website. [Online]. Available: http://www.peraturan.go.id/

[4] Hutasoit, dkk. Sistem Pendukung Keputusan Pemilihan Guru Terbaik Pada SMK Maria Goretti Pematangsiantar Menggunakan Metode Simple Additive Weighting (SAW). Jurnal Sistem Informasi \& Teknologi Informatika.2016.

[5] Hasugian, Humisar dan Putra, Esa.“ Sistem Penunjang Keputusan Pemilihan Pegawai Terbaik Dengan Metode AHP dan SAW Pada PT Sukma Jaya Mandiri”. Jurnal TELEMATIKA MKOM, vol.9 No.3.2017. 